DOI: $10.1515 / \mathrm{sjdv}-2016-0009$

\title{
Dress Syndrome - A Case Report
}

\author{
Zorana KREMIĆ1, Željko P. MIJUŠKOVIĆ ${ }^{1}$, Lidija KANDOLF-SEKULOVIĆ ${ }^{1}$
}

${ }^{1}$ Clinic of Dermatovenereology, School of Medicine, Military Medical Academy, Belgrade, Republic of Serbia

*Correspondence: Zorana Kremić, e-mail: kremicz@me.com

UDC 615.213.06:616.5

UDC 615.213.06:616.155

DE GRUYTER
OPEN

\begin{abstract}
The drug reaction with eosinophilia and systemic symptoms (DRESS) syndrome is an adverse drug-induced reaction that occurs most commonly after exposure to drugs, most frequently anticonvulsants, sulfa derivates, antidepressants, nonsteroidal anti- inflammatory drugs, and antimicrobials. We present a 61-year-old male, with a generalized maculopapular exanthema on the trunk, face, extremities, palms, soles, palate, and fever $\left(38^{\circ} \mathrm{C}\right)$. His medical history was notable for generalized epilepsy, treated with carbamazepine during 1 month. The diagnosis of DRESS syndrome was confirmed by specific RegiSCAR criteria. In our case, skin eruptions were successfully treated with oral methylprednisolone, cephalexin, and topical corticosteroid ointment.

In conclusion, although the mechanisms of this syndrome are not completely understood, numerous cases were reported in children and adults. This syndrome should be considered in every patient with skin eruption, fever, eosinophilia, liver and hematological abnormalities. Prompt recognition, supportive therapy and initiation of corticosteroids may prevent systemic manifestations.
\end{abstract}

\section{Key words}

Drug Hypersensitivity Syndrome; Signs and Symptoms; Case Reports; Diagnosis; Treatment Outcome

$\mathrm{T}$ he drug reaction with eosinophilia and systemic symptoms (DRESS) syndrome is a severe adverse drug-induced reaction, that occurs most commonly after exposure to drugs, such as anticonvulsants, sulfa derivates, antidepressants, nonsteroidal antiinflammatory drugs, and antimicrobials $(1,2)$. The drugs most frequently reported with DRESS syndrome are anticonvulsants. DRESS syndrome shares many characteristics with anticonvulsant hypersensitivity syndrome (AHS), also referred to as drug-induced hypersensitivity syndrome (DIHS), but it appears to be a variation, rather than a distinctly different syndrome (3).

DRESS syndrome has been found to represent the major cause of hospitalization for dermatologic complications in patients treated with anticonvulsants $(4,5)$.
The syndrome is characterized by severe skin eruption, fever, lymphadenopathy, hematologic abnormalities (eosinophilia, atypical lymphocytes), and internal organ involvement (liver, kidneys, lungs, heart, or pancreas) (6).

The incidence of DRESS syndrome is between 1 in 1,000 and 1 in 10,000 drug exposures, and it has a mortality rate of $10-20 \%(7)$. There may be a familial component associated with this condition.

The pathogenesis of DRESS syndrome is not well understood. Different mechanisms have been implicated in its development, and it is hypothesized to consist of a complex interaction between two or more of the following: 1) a genetic deficiency of detoxifying enzymes leading to accumulation of drug metabolites that bind to cell macromolecules causing cell death or inducing secondary immunological 


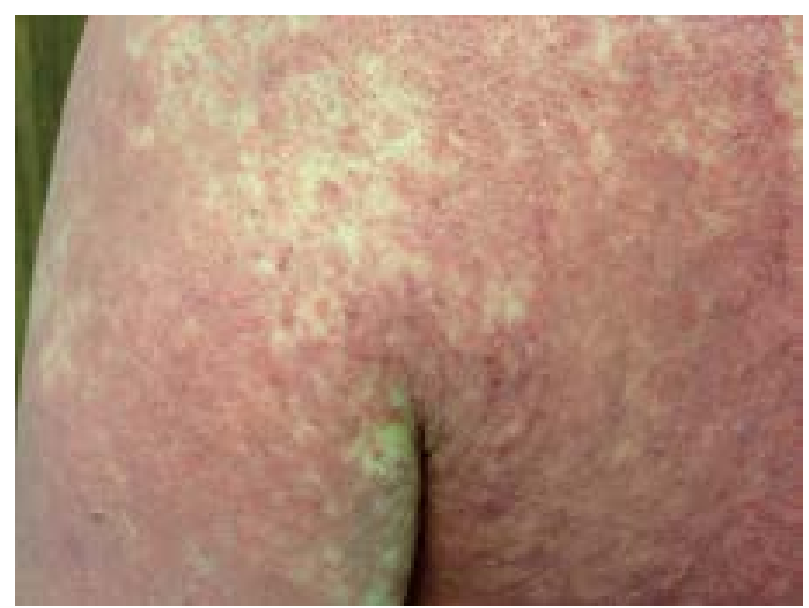

Figure 1. Generalized maculopapular eruption over the back and shoulders

response. Eosinophilic activation as well as activation of the inflammatory cascade may be induced by T-cell releasing IL-5 (9); 2) reactivation of human herpesvirus 6 (HHV-6), human herpesvirus 7 (HHV7), Epstein-Barr virus (EBV), or cytomegalovirus $(\mathrm{CMV})$ which may trigger a reaction (10), and

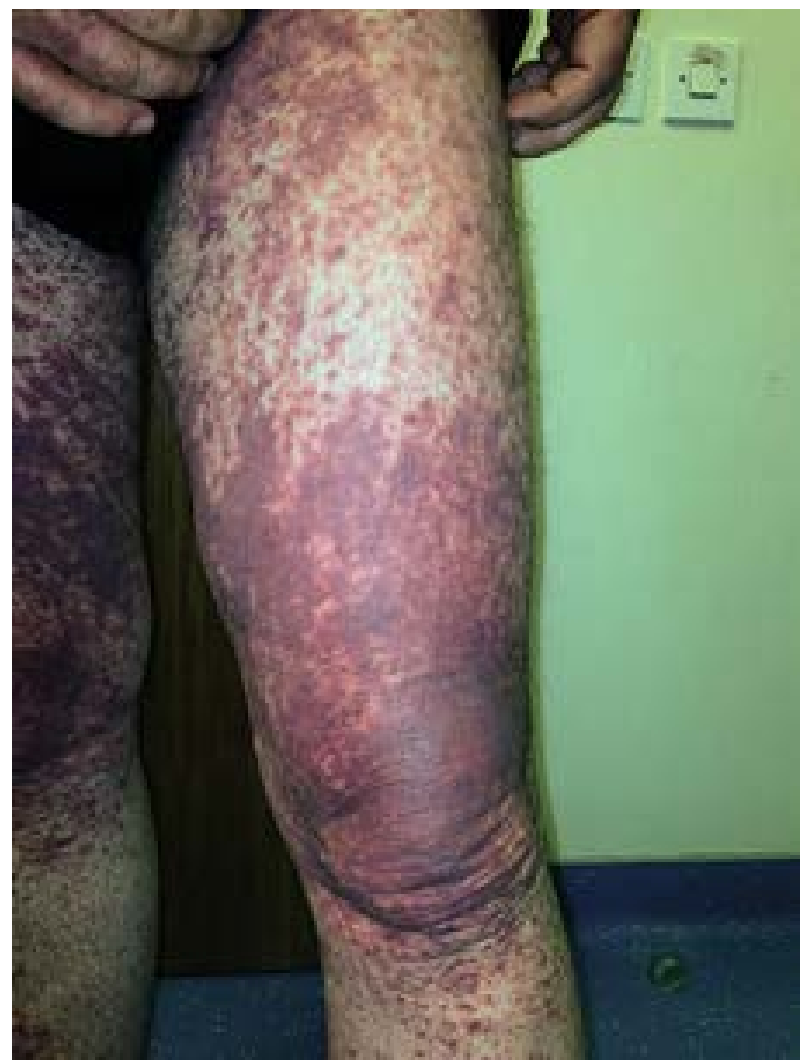

Figure 2. Maculopapular darkly livid erythema on the lower extremities

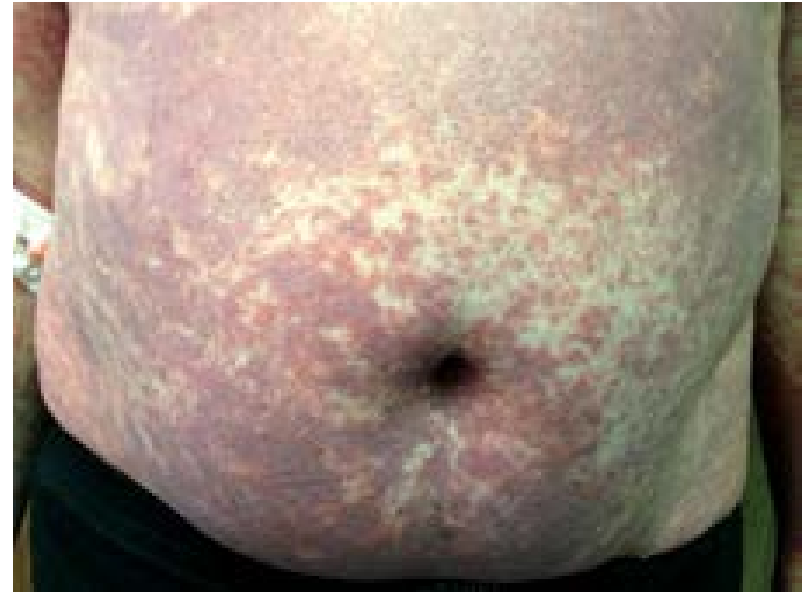

Figure 3. Generalized exanthema on the trunk

3) genetic associations between human leukocyte antigen (HLA) associations and drug hypersensitivity may occur. The genetic association of carbamazepineinduced drug hypersensitivity reactions is probably phenotype-specific $(9,11)$.

The symptoms are often delayed, anywhere between $2-8$ weeks after initiating the offending drug.

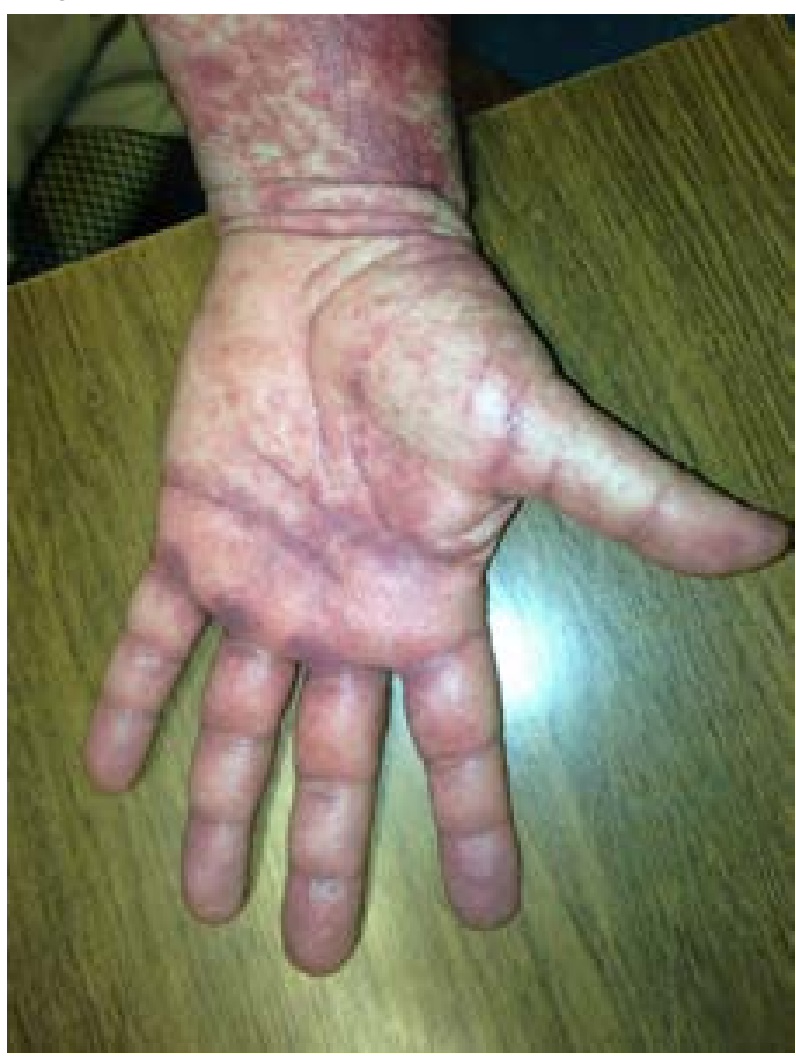

Figure 4. Maculopapular eruptions of the palms 


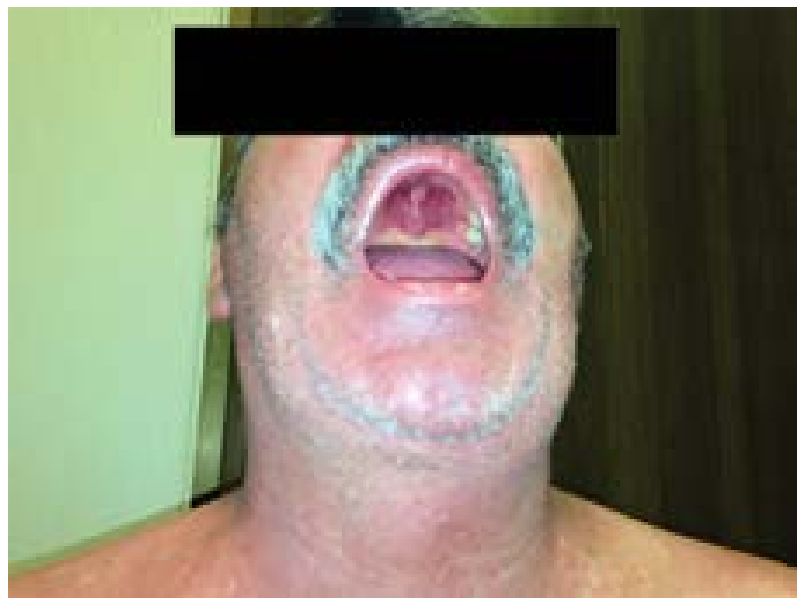

Figure 5. Palate exanthema

The most common clinical presentation includes skin eruption, fever, lymphadenopathy, abnormal liver function tests, etc.. Fever is the most common feature, seen in $90-100 \%$ of cases, and it may precede the cutaneous eruption (10). Eruption is present in $90 \%$ of cases. It is usually a macular erythema that becomes confluent and may generalize into erythroderma. Periorbital and facial edema may be severe and occurs in $25 \%$ of cases. Blistering can also be seen (4). Local or generalized and benign lymphoid hyperplasias are usually detected. Hematologic abnormalities are found in $50 \%$ of cases, and may include hemolytic anemia, thrombocytopenia, eosinophilia, leukocytosis, and atypical lymphocytes. Internal organ involvement includes transitory increase in liver enzymes, liver necrosis, and hepatitis, potentially lifethreatening conditions (12). Other fatal complications include pericarditis, pneumonitis, nephritis, pancreatitis, colitis, myositis, and meningitis.

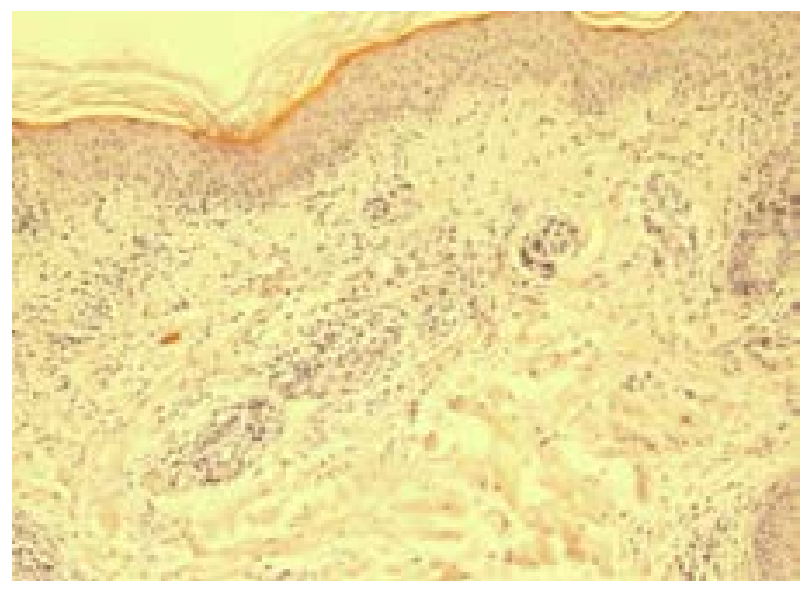

Figure 6. Vacuolar interface dermatitis

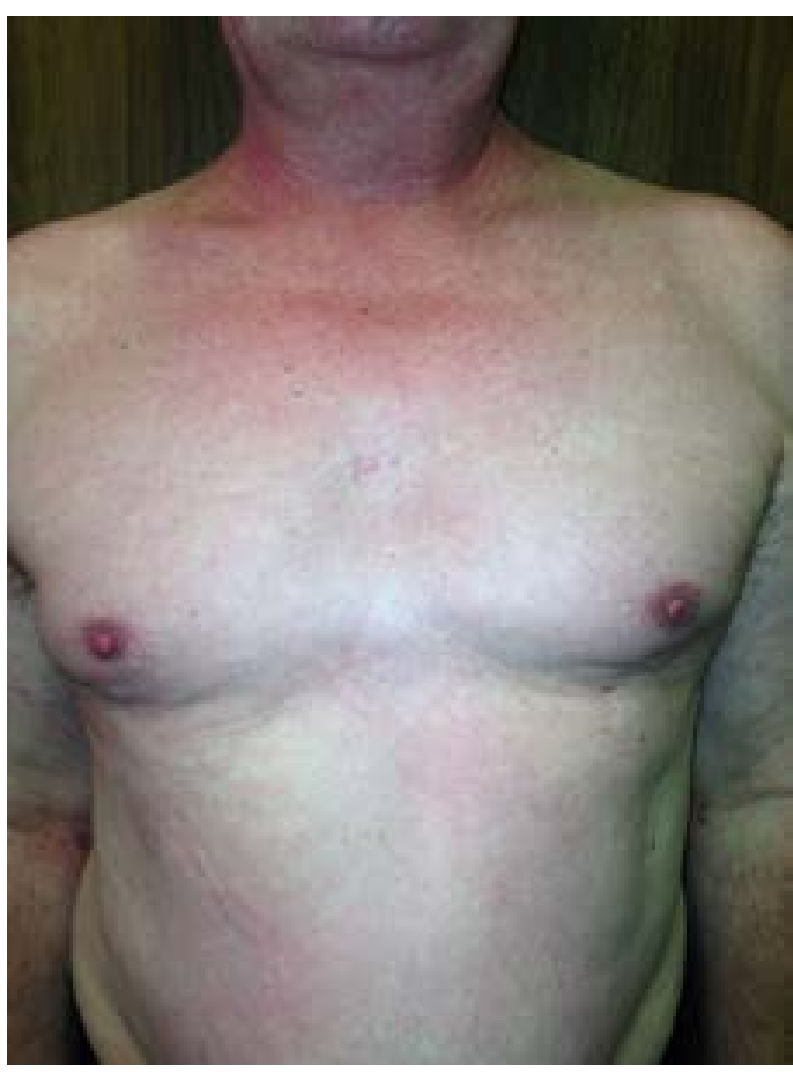

Figure 7. Residual hyperpigmented macules on the trunk

To make the diagnosis of DRESS syndrome, patients must have three of the four main RegiSCAR criteria: fever above $38^{\circ} \mathrm{C}$, lyphadenopathy at two sites, involvement of at least one internal organ, and abnormalities in lymphocyte and eosinophil counts.

The DRESS syndrome must be recognized promptly and the causative drug withdrawn. Patients with anticonvulsants-induced DRESS syndrome should not be treated with carbamazepine phenytoin and phenobarbital, because of the risk of crossreactivity amongst aromatic anticonvulsants. The treatment consists of supportive therapy, topical or oral corticosteroids, and antihistamines, maintenance of fluid and electrolyte balance.

\section{Case report}

We present a 61-year-old male, who was admitted to the Clinic of Dermatology and Venereology, Faculty of Medicine, Military Medical Academy in Belgrade with a skin eruption and fever $\left(38^{\circ} \mathrm{C}\right)$ lasting for 3 days. His medical history was notable for generalized epilepsy, 


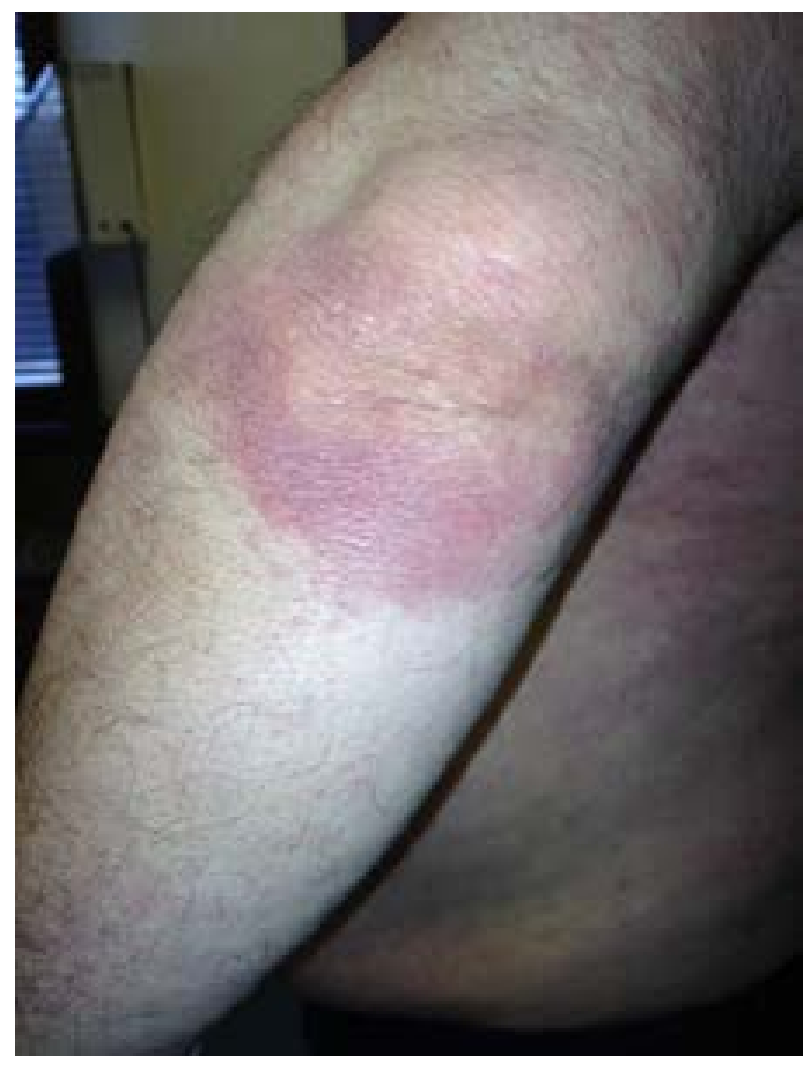

Figure 8. Erythematous macules on the arms treated with carbamazepine during 1 month. On physical examination he presented with a temperature of $38^{\circ} \mathrm{C}$ and headache. He also had a generalized maculopapular exanthema on the trunk, face, extremities, palms, soles, and palate. The blood report showed a white blood cell count of $18.95 \times 10^{9} / 1$, lymphocytes $7.61 \times 10^{9} / 1$, neutrophils $8.6 \times 10^{9} / 1$. A peripheral blood smear showed eosinophils $2 \%$. Liver enzymes were increased: aspartate aminotransferase (AST) $91 \mathrm{U} / \mathrm{L}$, alanine aminotransferase (ALT) 243 $\mathrm{U} / 1$, lactate dehydrogenase (LDH) $888 \mathrm{U} / \mathrm{L}$, g-glutamyl transpeptidase (GGT) $674 \mathrm{U} / \mathrm{l}$. The diagnosis of sepsis was established, based on microbiologic isolation of Staphylococcus aureus in blood culture and affected lesions. Antinuclear antibodies were negative. Proteins in 24-h urine were $0.464 \mathrm{~g} / 24-\mathrm{h}$.

Radiography of the heart and lungs and ultrasonography of the abdomen and pelvis showed no pathological findings.

Histopathological findings showed vacuolar interface dermatitis. The direct immunofluorescence test was negative. After consultation with a neurologist, carbamazepine was discontinued.
Methylprednisolone (80 mg/day) and cephalexin $2 \mathrm{~g} /$ day were immediately introduced, with topical corticosteroid ointment. The dose of methylprednisolone was gradually tapered.

After one month there was a complete remission of skin changes.

\section{Discussion}

The first documented cases of DRESS syndrome can be traced to hydantoin drugs as early as the 1930s, although a formal name for the syndrome was not coined until 1980s. The term DRESS syndrome was first presented in 1996s by Bocquet and colleagues (6).

The DRESS syndrome is most frequently caused by aromatic anticonvulsants (carbamazepine, phenytoin, and phenobarbital). The incidence of the DRESS syndrome due to aromatic anticonvulsants is approximately $1 / 5000$ exposures $(12-4)$.

Carbamazepine is an iminostilbene derivative chemically related to the tricyclic antidepressants. Carbamazepine induced adverse reactions have been reported in as many as $30-50 \%$ patients treated with this drug. Reactions to carbamazepine include: cutaneous, renal, hematologic and hepatic disorders. The most common cutaneous reaction is maculopapular eruption, occurring in up to $10 \%$ of patients $(10,15)$.

The onset of the disease has been reported to be 2.86 days (mean 35 days) after starting the offending drug (14).

Our case of DRESS syndrome has been reported with clinical features 4 weeks after the administration of carbamazepine. He had 4 of 5 diagnostic RegiSCAR criteria for DRESS syndrome. The clinical manifestations included acute maculopapular eruption, fever, liver and renal dysfunction, as well as blood abnormalities.

Using the Naranjo adverse drug reaction probability scale there was a presumable relationship (score of 5) between the development of the DRESS syndrome and treatment with carbamazepine $(2-8)$.

In the management of this syndrome it is of great importance to recognize the signs of stigmata and immediately discontinue the drug.

After meeting the RegiSCAR criteria for DRESS syndrome, our therapeutic approach was withdrawal of carbamazepine and administration of 
systemic corticosteroids and systemic antibiotics. The symptoms resolved within 4 weeks.

There were no recurrences, although relapse of the syndrome is often seen (17).

\section{Conclusions}

Although the mechanisms of DRESS syndrome are not completely understood, numerous cases have been reported in children and adults. The DRESS syndrome should be considered in any patient with skin eruption, fever, eosinophilia, or liver and hematological abnormalities, because this syndrome is a life-threatening multisystem adverse drug reaction. Prompt recognition, with supportive therapy and initiation of corticosteroids may prevent systemic manifestations.

All cases of DRESS syndrome should be reported to local pharmacovigilance centers.

\section{References}

1. Allam JP, Paus T, Reichel C, Bieber T, Novak N. DRESS syndrome associated with carbamazepine and phenytoin. Eur J Dermatol. 2004;14(5):339-42.

2. Seth D, Kamat D, Montejo J. DRESS syndrome: a practical approach for primary care practitioners. Clin Pediatr. 2008;47(9):947-52.

3. Buck ML. DRESS syndrome: examples from the pediatric literature. Pediatr Pharm. 2012;18(11).

4. Vittorio CC, Muglia JJ. Anticonvulsant hypersensitivity syndrome. Arch Intern Med. 1995;155(21):2285-90.

5. Tennis P, Stern RS. Risk of serious cutaneous disorders after initiation of use of phenytoin, carbamazepine or sodium valproate: a record linkage study. Neurology. 1997;49(2):542-6.

6. Bocquet $\mathrm{H}$, Bagot $\mathrm{M}$, Roujeau JC. Drug-induced pseudolymphoma and drug hypersensitivity (Drug rash with eosinophilia and systemic symptoms: DRESS). Semin Cutan
Med Surg. 1996;15(4):250-7.

7. Criado PR, Criado RF, Avancini JM, Santi CG. Drug reaction with eosinophilia and systemic symptoms (DRESS)/druginduced hypersensitivity syndrome (DIHS): a review of current concepts. An Bras Dermatol. 2012;87(3):435-49.

8. Lee JY, Seol YJ, Shin DW, Kim DY, ChunHW, Kim BY, et al. A case of the Drug Reaction with Eosinophilia and Systemic Synptom (DRESS) following isoniazid treatment. Tuberc Respir Dis (Seoul). 2015;78(1):27-30.

9. Choudhary S, McLeod M, Torchia D, Romanelli P. Drug reaction with Eosinophilia and Systemic Symptoms (DRESS) Syndrome. J Clin Aesthet Dermatol. 2013;6(6):31-7.

10. Ganeva M, Gancheva T, Lazarova R, Troeva J, Baldaranov I, Vassilev I, et al. Carbamazepine-induced drug reaction with eosinophilia and systemic symptoms (DRESS) syndrome: report of four cases and brief review. Int J Dermatol. 2008;47(8):853-60.

11.Hung SI, Chung WH, Liou LB, Chu CC, Lin M, Huang HP, et al. HLA-B*5801 allele as a genetic marker for severe cutaneous adverse reactions caused by allopurinol. Proc Natl Acad Sci USA. 2005;102(11):4134-9.

12. Kennebeck GA. Anticonvulsant hypersensitivity syndrome. J Am Board Fam Pract. 2000:13(5):364-70.

13. Peyriere H, Dereure O, Breton H, Demoly P, Cociglio M, Blayac JP, et al. Variability in the clinical pattern of cutaneous side effects of drugs with systemic symptoms: does a DRESS syndrome really exist? Br J Dermatol. 2006;155(2):422-8.

14. Mansur AT, Pekcan Yasar S, Goktay F. Anticonvulsant hypersensitivity syndrome: clinical and laboratory features. Int J Dermatol. 2008;47(11):1184-9.

15. Goodwin G, Consensus Group of the British Association for Psychopharmacology. Evidence-based guidelines for treating bipolar disorder: recommendations from the British Association for Psychopharmacology. J Psychopharmacol. 2003;17(2):149-73.

16. Ruble J, Matsuo F. Anticonvulsant-induced cutaneous reactions. Incidence, mechanisms and management. CNS Drugs. 1999;12(3):215-36.

17. Valencak J, Ortiz-Urda S, Heere-Ress E, Kunstfeld R, Base W. Carbamazepine-induced DRESS syndrome with recurrent fever ant exanthema. Int J Dermatol. 2004;43(1):51-4.

\section{DRESS sindrom - prikaz slučaja}

\section{Sažetak}

Uvod. DRESS sindrom, predstavlja reakciju na lek, koja se javlja u vidu generalizovane kožne erupcije, udružene sa eozinofilijom i sistemskim simptomima. Najčešće je izazvana antikonvulzivima, a takođe može biti izazvana i sulfa derivatima, antidepresivima, nesteroidnim antiinflamatornim lekovima, kao i antimikrobnim lekovima. Prikaz slučaja. Prikazujemo pacijenta starosti 61 godinu, sa generalizovanim makulopapularnim egzan- temom, na licu, trupu, ekstremitetima, dlanovima, tabanima, nepcu, kao i febrilnošću do $38^{\circ} \mathrm{C}$. Iz lične anamneze, dobijen je podatak da je pacijent, zbog generalizovane epilepsije, lečen karbamazepinom, tokom jednog meseca. Prateći zvanične kriterijume, postavljena je dijagnoza DRESS sindroma. U ovom slučaju, pacijent je uspešno lečen metilprednizolonom, cefaleksinom i topijskim kortikosteroidima. 
Zaključak. Iako etiopatogeneza DRESS sindroma nije u potpunosti jasna, opisani su mnogobrojni slučajevi. Dijagnozu ovog sindroma treba uzeti u obzir kod pacijenta sa generalizovanim kožnim promenama, povišenom telesnom temperaturom, eozinofilijom, kao i lezijama jetre i hematološkim poremećajima. Brzo ordiniranje odgovarajuće terapije može da prevenira sistemske manifestacije ove bolesti

\section{Ključne reči}

Sindrom preosetljivosti na lekove; Znaci i simptomi; Prikazi slučajeva; Dijagnoza; Ishod terapije 